\title{
PERCEPTION OF PERSONALITY IN THE CONTEXT OF WESTERN AND CHINESE PHILOSOPHY
}

\section{Kharyshyn D. G., Vorobei O. S.}

\section{INTRODUCTION}

Personalistic problems within the humanities became more active at the beginning of the $20^{\text {th }}$ century, when it became necessary to understand the essence of man not only in connection with his biological or social identity, but also depending on his personal nature. At this time the basis of the problems of personalism is laid - the "crisis of man", which is conceived as a crisis of modern civilization. The fundamental role in the conceptualization of man as a personality belongs to philosophy. Nevertheless, there has been a recent tendency to analyze philosophical concepts of a phenomenon from the perspective of the dialogue between the West and the East, which makes it possible to avoid their unilateral understanding.

Many Chinese (Yan Fu / 严复, Liang Qichao / 梁启超, Sun Yat Sen / 孙 中山, Chen Duxiu / 陈独秀, Li Dazhao / 李大钊), foreign (Ch. Holcomb, A.H. Smith, J. McGowan, M. Gran, etc.) including Russian (I. Korostovets, V. Korsakov, I. Baranov, V. Alekseev, K. Tertitsky, M. Speshnev, O. Radionov) missionaries, diplomats and scholars of the late $19^{\text {th }}$ century tried to understand the socio-psychological traits of the Chinese national character. But almost no attention to the study of man as an individual was paid in China. The reason for this was the unacceptability of the idea of an independent individual since ancient times in China. At the same time, on the West, the conceptual awareness of an independent personality appeared only in the late $19^{\text {th }}$ - early $20^{\text {th }}$ century, particularly, in the works of philosopher-personalists Nikolai Berdyaev ("About slavery and human freedom. The experience of personalistic philosophy") and Emmanuel Munier ("A Personalist Manifesto", "What is personalism?", "Personalism").

"Human personality" is a concept that has been substantially differently formed within the Western and Eastern philosophical models of existence. According to N. Hamitov's statement, "the basic values of the Western way of existence are personality, the practice of technical transformation of nature, history", while on the East, "the basic principles are naturalness, fatalism and inevitable gratitude (karma)" [semi-bold text corresponds to 
the source $]^{1}$. This conclusion is related to, first and foremost, the autonomous ways of development of Western and Eastern civilizations prior to the beginning of their dialogue, which was intensified in the $20^{\text {th }}$ century. At that time, Western natural, economic, social and philosophical theories had an active influence on the formation of foundations for the further development of man and society in the minds of Eastern thinkers, which is also entirely relevant to China. As a matter of fact, the traditional conception of the essence of man here started to change actively. However, it is necessary to clarify the meaning of the term "personality", which was detailed in the writings of European personal philosophers. The term would make it possible to argue or deny the possibility of forming a similar understanding in China.

\section{Personality as a research point of Western philosophy studies}

Personalism is a trend in philosophy, "where personality and its spiritual values are recognized as the highest content of civilization" $"$. As a way of human existence, personalism "affirms the fundamental value of being a free, creative personality"3. This trend was formed in the late $19^{\text {th }}$ century in Russia and America, and in the 30's of the $20^{\text {th }}$ century - in France and other European countries. Many thinkers have supplemented the theory of personalism with their ideas, but within the framework of our study we are going to focus on the works of M. Berdyaev (1874-1948) and E. Munier (1905-1950), who substantiated a clear coordinate system for determining the essence of the human personality through the lens of antinomy "personality - society". However, before referring to these authors, it is necessary outline the previous trends in brief.

In his writings $M$. Berdyaev provides an overview of philosophical concepts about the nature of the human personality that existed in the European tradition before a personalism has appeared. It is clear that the author assesses them from the point of view of the degree of conformity to the personalistic theory. His remarks fully reproduce the direction of the development of philosophical understanding of the human personality in Europe from the times of Ancient Greece to the beginning of $20^{\text {th }}$ century.

M. Berdyaev insists that in the ancient Greek philosophy, represented by the works of Plato, Aristotle and Plotinus, the idea of personality is absent. It appears briefly in the Stoics, and then develops in the theological doctrines

\footnotetext{
${ }^{1}$ Хамітов Н., Гармаш Л., Крилова С. Історія філософії: Проблема людини та іiі меж : навчальний посібник. Київ : КНТ, 2016. С. 18.

2 Персонализм. Новая философская энциклопедия. URL: http://iph.ras.ru/elib/ 2302.html (retrieved 25.01.2020).

${ }^{3}$ Хамітов Н., Гармаш Л., Крилова С. Історія філософії: Проблема людини та іiі меж : навчальний посібник. Київ : КНТ, 2016. С. 222.
} 
of the Holy Trinity. M. Berdyaev proves that this is where the awareness of God as a person is born, preceding to the awareness of man as a person. The term «personality» (derives from the Latin word Persona - mask, role, person) as a philosophical category was introduced by Boethius (Boethius, 480-525) - the founder of the medieval scholastic philosophy. In his treatise "Against Eutyches and Nestorius", the philosopher gives a notorious definition: "persona is the indivisible essence of rational nature" (persona est naturae rationalis individua substantial $)^{4}$. That is, the personality is related to the consciousness and mind. In this way, it is being interpreted within the philosophy of Thomism.

An important change of the understanding of the personality M. Berdyaev founds in works of I. Kant, who switches from intellectualistic to the ethical understanding of the personality. That is, the personality is treated independently of the determinism of nature as a "goal in itself". There is an illustrative notorious Kant's categorical imperative, which closely links morality and freedom. A personality must solvehis moral problems based on the freedom of his will. The ability of a person to determine good and evil, as well as to be accountable for his actions is interpreted as a creative act.

A significant contribution to the development of ideas about the nature of the human personality was made by proponents of Individualist Anarchism, in particular by Max Stirner (1806-1856). In his work "The Unique and Its Property" he presents the conception of will, spirituality, freedom, creative realization as the attributes of human personality. Researchers, including M. Berdyaev, point out M. Stirner's theory to be complex and someway contradictory. It has something in common with the ideas of the theorists of "voluntarism" (A. Schopenhauer and F. Nietzsche), as well as existentialist philosophers. Having carefully analyzed the various components of the concept of "personality" of Stirner's philosophy, in his dissertation P. Ryabov noted that Stirner's innovation boiled down to three basic provisions: "a) to the idea of singularity, the uniqueness of the personality $\langle\ldots\rangle$; b) to the idea of property and sovereignty $\langle\ldots\rangle$; c) to the idea of unity, the spiritual and physical value of the individual" ${ }^{\prime 7}$. Berdyaev criticizes M. Stirner's ideas for immersing himself into the dialectic of self-

4 Боэций. Новая философская энциклопедия: в 4 т. / под ред. В.С. Стёпина. Москва : Мысль. 2001. URL: http://dic.academic.ru/dic.nsf/enc_philosophy/ 162/БОЭЦИЙ (retrieved 25.01.2020).

5 Бердяев Н. О рабстве и свободе человека. Опыт персоналистической философии. Царство Духа и Царство Кесаря. Москва : Республика, 1995. С. 20.

${ }^{6}$ Штирнер М. Единственный и его собственность. Харьков : Основа, 1994. 560 с.

${ }^{7}$ Рябов П. Проблема личности в философии классического анархизма : дисс. канд. философ. наук. Москва, 1996. URL: http://royallib.ru/book/ryabov_petr/ problema_lichnosti_v_filosofii_klassicheskogo_anarhizma.html (retrieved 25.01.2020). 
affirmation, but finds a positive meaning in the concept of "The Unique", pointing to personality as a whole or a microcosm.

M. Berdyaev's philosophical conception was born out of his own sense of "foreignness of the world" and "longing for the transcendental" , caused by a living far from home, a misunderstanding of his ideas by contemporaries. In M. Berdyaev's works "The crisis of man» is especially acute in the existential sense. The crisis expresses itself in the impossibility of realizing human opportunities outside the society and in a certain confrontation of personality with the society, as well as in the struggle for one's personal identity, which cannot be dissolved in the human masses. External confrontation turns into an internal crisis, stimulating the desire of the individual to intensify activity, creativity and self-creation.

The concept of "personality" in his writings is not just a concise definition but is detailed through a number of defining features. First, a person is considered as a microcosm that cannot be a part of any hierarchy. Therefore, it cannot be recognized as just an object of one's kind, as anthropological sciences, biology, psychology and sociology are willing to ${ }^{9}$. As a result, as it is emphasized by a Russian researcher O. Gorokhov, towards all philosophical trends that seek to dissolve the individual in the whole, or to reduce its essence to self-centeredness and arbitrariness M. Berdyaev treats in a negative manner ${ }^{10}$.

An important concept in understanding the nature of M. Berdyaev's personality is creativity. Experiencing the power of creative inspiration in his own experience, he states that "personality is not a ready-made gift, but is a task, an ideal of man" "11. In other words, these are the potential opportunities that a person must expand and enrich, constantly changing himself at the same time. One of the ways of realization of these potential opportunities is a creative act. It refines the nature of a man and distinguishes it among others as the only, exclusive and unique one. According to M. Berdyaev, "a person must carry out original creative acts, that forms him as a person, creates his value" ${ }^{12}$. Of course, by "creativity"

8 Бердяев Н. Самопознание (Опыт философской автобиографии). Москва : Книга, 1991. С. 9.

9 Бердяев Н. О рабстве и свободе человека. Опыт персоналистической философии. Царство Духа и Царство Кесаря. Москва : Республика, 1995. С. 13.

10 Горохов А. Н.А. Бердяев и Э. Мунье (два опыта построения персоналистической философии). Вече. Журнал русской философии и культуры. 2009. № 19. С.115.

11 Бердяев Н. О рабстве и свободе человека. Опыт персоналистической философии. Царство Духа и Царство Кесаря. Москва : Республика, 1995. С. 13.

12 Бердяев Н. О рабстве и свободе человека. Опыт персоналистической философии. Царство Духа и Царство Кесаря. Москва : Республика, 1995. С. 14/ 
the author understands not only the art, but also a culture as a whole. Man is forced to realize himself in society and to create in any sphere of his activity: philosophy and science, art and literature, family life, economy and technology. A creative act involves the activity of a person as a necessary condition for the unfolding of one's personality. Everything beyond creativity is passivity. According to M. Berdyaev's statement, "Personality is an activity, resistance, victory over the burden of the world, the rule of freedom over the slavery of the world. Avoiding the efforts of a hostile realization of the individual" 13 .

M. Berdyaev connects the nature of the human personality with the need of achieving freedom in the sense of the inner being of man (in its existential sense). Freedom implies an inwardness of a person resisting the needs of the material world. But according to M. Berdyaev, only Christ could achieve an absolute freedom, since he was free from the world and was influencing others only by his love. To explain the internal state of individual's freedom and to distinguish this state from social correlation, M. Berdyaev distinguishes three types of human consciousness - "a master", "a slave", "a free". The master expresses one's existence through the mediation of another one, the slave - through the existence for the sake of another (these concepts are correlative). The consciousness of the free is the existence of a person only for itself with the free possibility join others ${ }^{14}$. Thus, freedom is a return of one's spiritual nature to a man, while the slavery is always "an alienation or ejection beyond the limits of human natur" ${ }^{\prime 15}$. Interpreting freedom, a very important point in is the fact of the dependency of a tyrant (master) on a slave. The tyrant can never become spiritual and free as the tyranny is only the reverse side of the slavery. To enslave another means to enslave oneself. Unlike Christ, who never had the will to power, Caesar was a slave, "a slave of the world, a slave of the will to power, a slave of the human masses, without which he could not implement the will to power" ${ }^{16}$. Consequently, neither a slave nor a master can be a personality, since they are longing for unfreedom. Only a free can be a person, even if he is wished to be conquer by others.

Furthermore, providing a definition to the essence of the human's personality, M. Berdyaev overcomes the Cartesian mind-body dualism. He

13 Бердяев Н. О рабстве и свободе человека. Опыт персоналистической философии. Царство Духа и Царство Кесаря. Москва : Республика, 1995. С. 14.

14 Бердяев Н. О рабстве и свободе человека. Опыт персоналистической философии. Царство Духа и Царство Кесаря. Москва : Республика, 1995. С. 35.

15 Бердяев Н. О рабстве и свободе человека. Опыт персоналистической философии. Царство Духа и Царство Кесаря. Москва : Республика, 1995. С. 36.

16 Бердяев Н. О рабстве и свободе человека. Опыт персоналистической философии. Царство Духа и Царство Кесаря. Москва : Республика, 1995. С. 36. 
affirms the vital unity of body and soul and presents a man as a synthesis of the spiritual-mental-corporeal. In this triad, the special role is given to the spirit, which shapes a body and soul and, as a consequence, forms the personality in its entirety. "The rehabilitation" of corporeality and the recognition of the positive features of a human body as individuating a person, is opposed by M. Berdyaev to the Christian disdain for the body as a matter personifying the individual ${ }^{17}$.

M. Berdyaev clearly draws the boundary between a personality and an individual. The individual is considered to be of biological, naturalistic and sociological category. It is a specific expression, part of a whole - kind, society, natural environment. The individual is closely associated with the material existence of man, that is, a peculiar opposite of personality. These are different forces that coexist inside a man. "An individual", says M. Berdyaev, "is experiencing an isolation, he is self-centered and passionate about struggling for life ... He overcomes difficulties through conformism and adaptation" 18 . Unlike an individual, personality is of the spiritual category that demonstrates independence from the material world and appears in the process of spiritual and moral creative activity of man.

Thus, in M. Berdyaev's personalistic concept, a personality appears as a potential opportunity for a person to develop a higher spiritual essence in the process of creativity. Characteristic features of the personality are moral and spiritual activity, resistance to the world, where a threat of enslavement exists, the acquisition of inner freedom, recognition of the corporealspiritual-mental unity of man, acceptance as an example of the image of God-Man. Personality opposes to individual the same way as the spiritual opposes to the material. Of course, our conclusion does not cover the conceptual depth of M. Berdyaev's personalistic philosophy but outlines the characteristics of the human pers onality that are significant to our study.

An important contribution to the investigation of the fundamental traits of the human personality was made by a French personalist grouped around "Esprit" journal. Their leader, E. Munier, was an adherent of M. Berdyaev's ideas; however, the answer to the question of the qualitative characteristics of personality he was searching in works of Socrates, Cicero, Descartes, Leibniz, Kant, Pascal, Mulbranche, Rousseau, Firche, Proudhon, Scheler, Bergson, Dostoevsky, Tolstoy, Marx, Lenin ${ }^{19}$. He largely sociologized the theory of personalism, focusing not only on the problem of personality but

17 Бердяев Н. О рабстве и свободе человека. Опыт персоналистической философии. Царство Духа и Царство Кесаря. Москва : Республика, 1995. С. 36.

18 Бердяев Н. О рабстве и свободе человека. Опыт персоналистической философии. Царство Духа и Царство Кесаря. Москва : Республика, 1995. С. 21-22.

19 Вдовина И. С. Личность в современном мире. Манифест персонализма. Москва : Республика, 1999. С. 3. 
also on the problem of creating a personalistic society. The French thinker outlined his ideas in his works "A Personalist Manifesto", "What is personalism?", "Personalism".

E. Munier defines personality as "a spiritual creature constituted in the way of being and autonomy in its existence; $<\ldots>$ it carries out its activity in the space of freedom and through the creative acts it develops its vocation in all its diversity ${ }^{20}$. This definition in general respects in line with M. Berdyaev's views, in particular on the issues of the unity of being a personality, its identity, spirituality, freedom, creative self-realization, etc., so it is only necessary to emphasize the social aspect of Munier's theory, realized through the dichotomy "personality - community". The sense of human community, the French thinker refers to the fundamental characteristics of personality: "Personality exists only in its pursuit of the "other", knows himself only through another and acquires himself only in "another" $"$. Therefore, the existence of the individual is determined only by its realization in the community: "I exist to the extent that I exist for another, and at last to be means to love. This is the original truth of personalis m" 22 .

The fundamental ideas of French personalism are determined through artistic creativity. The journal "Esprit" has gained not only fame for its plurality of thought by the intelligentsia published in it, but also for its contribution to the development of the arts and literature as a means of embodying personal ideas. According to I. Vdovina, the artist due to the concept of Munier "acted as a preacher and conductor of personal existence, and the works of art were considered a model of true personal selfembodiment" ${ }^{\text {"23. }}$.

Therefore, we must conclude that the concept of "personality" in the philosophical paradigm of European thought was shaped differently in various historical periods. This process was influenced by numerous religious and philosophical theories, within which personality was always thought not as a whole, but as part of something: part of "rational nature" (Boethius), part of "hierarchically correlated populations" (A. Karsavin) etc. Only at the end of $19^{\text {th }}$ and at the beginning of $20^{\text {th }}$ centuries in the context of the ensuing "crisis of man" in the terms of the rapid development of bourgeois society, the problem of awareness of the essential features of the individual as a microcosm, which fully devoid of signs of partiality, dependence, conformism, subordination, etc. became urgent. Personalistic

${ }^{20}$ Мунье Э. Манифест персонализма. Москва : Республика, 1999. С. 300.

${ }^{21}$ Мунье Э. Манифест персонализма. Москва : Республика, 1999. С. 479.

${ }^{22}$ Мунье Э. Манифест персонализма. Москва : Республика, 1999. С. 479.

23 Вдовина И.С. Личность в современном мире. Манифест персонализма. Москва : Республика, 1999. С. 8. 
philosophers have left particular and material dependence within concept of "individual", instead put the personality in the center of being and identified its fundamental traits: spiritual-mental-physical unity, active moral position, resistance to violence, manifestation of spiritual es sence through creative act, reality through love, freedom from material and any other dependencies.

\section{Perception of the personality in China: diachronic approach}

Could such an understanding of a personality be crystallized in the mental space of the Oriental people, including the Chinese? Unfortunately, this question is not often found in the works of modern sinologists. Researchers are more interested in the national character of the Chinese, closely related to the traditions of life of the people, and quite closely related to the concept of "personality" of the individual. National character refers to the set of persistent mental properties of a pers on as a member of society, which manifest themselves in its relation to reality and imprint on its behavior and actions. The national character is determined to be the aggregate of socio-economic, historical and geographical circumstances of existence of the ethnic group. The factors that shape the national character are:

- the natural conditions in which the nation lives;

- type of business activity;

- the nation's genetic fund;

- the type of society in which it lives;

- spiritual foundations of the nation (religious, ideological).

The national character is most clearly manifested in literature and art, in folk tunes, dances, proverbs, sayings ${ }^{24}$.

In China, philosophers, political and public figures, and writers have also dealt with issues of national character. For example, such famous Chinese people as Yan Fu (严复, 1854-1921), Liang Qichao (梁启超, 1873-1929), Sun Zhongshan (孙中山, 1866-1925), Chen Duxiu (陈独秀, 1879-1942), Li Dazhao (李大钊, 1889-1927) and others.

In Ukrainian and foreign Synology studies the problem of Chinese ethnopsychology has always attracted the attention of researchers. The first observations of foreign missionaries, diplomats, and scholars, especially the Russian ones, who travelled to China at the end of $19^{\text {th }}$ and at the beginning of $20^{\text {th }}$ centuries are quite valuable. Usually, these are essays that describe the life and customs of ancient China, focusing on both the positive and negative features of the Chinese national character.

24 Спешнев Н.А. Китайцы: особенности национальной психологии. Санкт Петербург : КАРО, 2011. С. 15, 17. 
Therefore, M. Speshnyev in his research notes that one of the productive methods of studying the psychology of Chinese is the analysis of works written by Chinese writers, where could be found thoughts on this topic or where are compared the features of national character with the psychology and actions of representatives of other countries (more often Europeans and Americans). The following famous works of Chinese writers can be mentioned here: “The besieged fortress" by Qian Zhongshu (钱锤书, 19101998), travel notes by Feng Jitsai (冯骥才, 1942), and, of course, the works of Lao She as a whole, to which the monograph, written by Russion sinologist O. Radionov "Lao She and Problems of National Character in Chinese Literature of the XX century" (2006), was fully dedicated. O. Radionov analyzes the method of comparing the psychology of Chinese and foreigners of the end of 20's - beginning of 30-ies of the twentieth century in the works of Lao She ${ }^{25}$.

Therefore, many works are devoted to the studies and disclosure of the most prominent socio-psychological traits of the national character of the Chinese, their habits and customs, which allow to depict an aggregate portrait of the people, which reflects its identity. However, slight attention is paid to human exploration as a person in China. The concept of "national character" was only tangentially related to the human personality. After all, a person as a subject of social relations is primarily characterized by autonomy, a degree of independence from society, the ability to fully identify their potential for a clearerself-identification of theirnation ${ }^{26}$. Personal independence is combined with the ability to control oneself, which involves the presence of selfconsciousness, that is, not only about thinking and will, but also about the capacity for self-analysis, self-esteemand self-control. The self-consciousness of the personality is transformed into a life position ${ }^{27}$.

In traditional Chinese dictionaries, for instance in Qiuan (《辞 源》, 1915) and Qihai (《辞海》, 1936), the concept of gexing (个性), which today is most commonly used in the meaning of "personality" (though combining "character" and "personality" meaning as well) is missing. The reason is that, in ancient times, there was no such concept in China at all: it did not recognize the independent existence of the individual. This is

25 Спешнев Н.А. Китайцы: особенности национальной психологии. Санкт Петербург : КАРО, 2011. С. 37-38.

${ }^{26}$ Крысько В.Г. Этнопсихологический словарь. Национальная психологическая энциклопедия. URL: http://vocabulary.ru/dictionary/1067/word/lichnost (retrieved 25.01.2020).

27 Крысько В.Г. Этнопсихологический словарь. Национальная психологическая энциклопедия. URL: http://vocabulary.ru/dictionary/1067/word/lichnost (retrieved 25.01.2020). 
explained by the socio-economic circumstances under which China lived for many centuries ${ }^{28}$. Traditional ideological and ideological principles treat individuality only as a not very interesting supplement to the social role and functions of the $\operatorname{man}^{29}$. In modern dictionaries, the concept of gexing, as well as synonymous concepts such as renge (人格) and geren (个人), can mean "personality", "nature", "character", "individuality" 30 .

The Chinese people are often compared to a pile of sand in which an individual is worthless, and all people together have power and mightiness. Certainly, the Chinese perceive their social environment as part of their personal destiny. They are much more dependent on society than Europeans. At the heart of Chinese culture is a commitment to the idea of a common and harmonious life for people ${ }^{31}$.

Human being as a socially creature was the point of interest of Chinese thinkers for many centuries. Traditional Chinese culture has sought the harmony of man and the universe, and peculiar attention has been paid to the ethics of the individual. It was based on religious -philosophical teachings Confucianism, Taoism and Buddhism - which complemented each other, defined the moral foundations of the Chinese people, and were based on concepts and principles such as Heaven (天), Tao (道), fate (道), courage (勇), circumspection (谨), humanity (仁), adherence of etiquette (礼仪), wisdom (智慧), devotion (忠), thrift (节俭), filial respect (孝顺), respect for elders (悌), prudence (理智), fidelity (信), etc.

Confucianism is the spiritual foundation of Chinese culture. The teachings of Confucius greatly influenced the thinking and national character of the Chinese. Early Confucianism was aimed at how to make a person out of a human being, how to dislodge an animal from it, how to bring up in it a sense of responsibility for the affairs in society and nature ${ }^{32}$. Scilicet, Confucianism was interested only in the relation of the person to the world and how to use his talents and abilities in the most appropriate way. In Confucian doctrine, the most valuable are the statements of Heavenly control, ethics, and morality. The concept of "state" - guojia (国家) became

28 Спешнев Н.А. Китайцы: особенности национальной психологии. Санкт Петербург : КАРО, 2011. С. 22-23.

29 Т оропцев С.А. От схемы к характеру [Изображение человека в литературе и искусстве Китая]. Вопросы литературы. 1983. № 10. С. 86-88.

30 Большой китайско-русский словарь / БКРС. URL: http://bkrs.info (retrieved 25.01.2020).

${ }^{31}$ Macgowan, John. Sidelights on Chinese Life. London: K. Paul,Trench, Trübner \& co., limited, 1907. P. 17.

32 Личность в традиционном Китае: сборник статей / редкол. : Л.П. Делюсин (отв. ред.) и др. Москва : Наука. Изд. фирма «Вост.лит», 1992. С. 4. 
an extension of the concept jia (家), which stands for "family", «household». And the loyalty to the governor became an extension of the concept xiao (孝), which stands for "respect", especially parental authority in the family ${ }^{33}$. This, of course, could not facilitate the development of the individual: social structure and subordination put the person in a secondary position - all had to serve a single cause - order in the state - each in its place.

However, in Confucianism the idea of the necessity of self-education, self-development of man, his uniqueness as a person was invariably held. According to Confucius, it is not enough to be born a man, it is necessary to give birth to a man inside of you. The Confucian school believes that the main criterion for the behavior of a decent person is the moral standards that this person must follow ${ }^{34}$.

Confucius clearly distinguishes people of different social status, depending on the moral qualities, in which sees superhuman meaning, and, thus, affirms the inevitability and inviolability of social stratification ${ }^{35}$.

For example, according to the Confucian tradition, people were divided into several categories: junzi (君子) - noble men, xiaoren (小人) - worthless people, and ren (人) - ordinary, common people. Man was considered only as part of the social hierarchy, where he occupies a certain place. Therefore, the doctrine of man is inseparable from the doctrine of government. However, within the framework of the ancient Chinese cultural tradition, such a hierarchy was not a humiliation of the individual, but, on the contrary, was a guarantor of social order and harmony.

In China, the clan was treated as much more important thing than the individual who was only the part of it. Everyone had to be content with its place and carefully perform its social function, established by ethical standards, as well as to maintain harmony in the clan, leaving their opinions and their experiences with them. This makes it possible to say that the Chinese tend to subjugate a person of higher social status and are willing to take strict control of their own behavior, are ready to accept respectful traditions, law-abiding instead of defending their personal interests and adhering to their principled position ${ }^{36}$.

Peace and stability in society, maintaining harmony in the relationship between human activity and nature, avoiding disturbances in the relationship between Heaven (天), Earth (地) and Man (人) - this was the main purpose

${ }^{33}$ 启良。中国文明史。广州：花城出版社, 2001年。第168页。

34 Личность в традиционном Китае : сборник статей / редкол. : Л.П. Делюсин (отв. ред.) и др. Москва : Наука. Изд. фирма «Вост.лит», 1992. С.4.

${ }^{35}$ 中国儒家学术思想史。济南：山东教育出版社1996年。第576页。

36 Спешнев Н.А. Китайцы: особенности национальной психологии. СанктПетербург : КАРО, 2011. С. 25. 
of the educational efforts of Confucius and his followers (in particular Menzi and others). That is why Confucius and his disciples attached great importance to self-education, observance of norms of behavior, education of personality, duty and justice, without which neither a person nor an ideal society can be formed nor put into order in the Celestial (天下) $)^{37}$.

Confucianism came up with a "the golden mean" (中庸) approach to the cognition of the objective world, so that this teaching could not go on severe ignoring of other philosophical thoughts. In the process of strengthening the spiritual control of feudal autocracy over the whole society, Confucianism accepted and served many tenets of Taoism, which, in turn, were consonant with the corresponding statements of Confucianism. As for a person and its personality, both doctrines envisaged the need for change in order to approach the "true essence of man". But the Taoist doctrine was not about morality and social well-being. In the Taoism worldview the noble man, an active "man of culture", is opposed to his antipode - a passive "man of nature", who does not recognize the influence of society and the authority of the governor. Taoism is focused on individual improvement. Moral growth comes naturally by uniting a person with the Tao (道 - usually is treated as the right way, the principle of life, the wise and just order, the exemplary norms of behavior, the embodiment of truth and justice, the principle of due and noble), and not implanted from the outside. This means that human behavior is much less restricted by conditional norms ${ }^{38}$. Due to the Taoist worldview, social rules and norms are perceived as:

1) violence against a person;

2) conventionality, artificial formation, which in this way prevents the manifestation of the true essence of man;

3) a factor that increases the separation of man from the world.

Due to the Taoism teaching the genuine purpose of human existence is proclaiming the individual's attainment of a state of complete identity with the essence of the world, through the dis solution of its es sence in nature and through its merger with the Tao as a universal primordial being. This is the principle of "naturalness" - ziran (自然). The main method of achieving a state of "naturalness" is "inaction" (无为). The Taoist principle of "inaction" was expressed in reversal of social activity, the pursuit of one's own instinctive impulses and free creative development, which is fundamentally contradicts

37 Личность в традиционном Китае : сборник статей / редкол.: Л.П. Делюсин (отв. ред.) и др. Москва : Наука. Изд. фирма «Вост. лит», 1992. С. 4.

38 Смирнов А. Даосизм и конфуцианство: единство и борьба противоположностей. URL: http://shkolazhizni.ru/archive/0/n-46130/ (retrieved 25.01.2020). 
Confucian customs about the need to follow the etiquette - $l i$ (礼), which leads Chinese society to external social and internal spiritual conflicts ${ }^{39}$.

Speaking about the Buddhismteaching as one of the three main religious and philosophical doctrines of China, we should notice, that from the very beginning of its development (approx. VI-V BC), the focus of Buddhism was on the human being. The starting point in the search for truth for the Buddha was the idea of the infinite suffering of human during its existence ${ }^{40}$. The impetus for the evolution of this philosophical thought was the need to answer the question: if life is suffering, and ending suffering means getting out of sams ara, then how the one can get out of this existence. One of the important points in Buddhist philosophy is the assertion that there is no individual " $\mathrm{I}$ ". The recognition of the existence of the individual "I" is treated in Buddhism as ignorance. This ignorance also gives rise to an idea of the existence of an individuality, which, being fascinated with its human being, is fully inspired by the whirlwind of life and creates affection for life ${ }^{41}$.

The essence of Buddhism is set forth in the doctrine of "four noble truths":

- The first of them states that life in the world is full of suffering. Birth, old age, illness, death, grief, desire, despair - everything that is raised from affection towards earthly is suffering. Suffering is not just accidental, it exists everywhere; even pleasure is a source of suffering.

- The second "noble truth" says that there is a cause of these sufferings and it is contained in the man himself: it is his thirst for life, pleasure, power, wealth. Suffering is the result of being born in this world, because birth has tight connection with thirst for everything on Earth. And our desires are elevated out of ignorance. If we understood the structure of the world and the causes of suffering, we would not have a passion for the Earth things. Then the birth would cease, and so does the suffering.

- The third "noble truth" states if the conditions that cause suffering could be eliminated, then the suffering itself would cease as well, and the state of liberation will come - nirvana (literally "damping", "destruction") the damping of passions, the guarantee of rebirth.

- The fourth "noble truth" indicates the path that leads to liberation from suffering, the so-called "noble mid octal path", which consists of

39 Смирнов А. Даосизм и конфуцианство: единство и борьба противоположностей. URL: http://shkolazhizni.ru/archive/0/n-46130/ (retrieved 25.01.2020).

${ }^{40}$ Коваль С., Холин Ю.Е. Дух воина. Дзэн и проблема человека. Краснодар : Маерли, 1993. С. 54.

${ }^{41}$ Торчинов Е.А. Учение о «Я» и личности в классическом индийском буддизме. URL: http://psylib.org.ua/books/_torch01.htm (retrieved 25.01.2020). 
"righteous gaze, right striving, right language, righteous behavior, righteous living, righteous teaching, righteous contemplation, righteous selfabsorption", which is commonly called meditation ${ }^{42}$.

Buddhists assured that the passing of the octal path guarantees the person complete spiritual reassurance, which cannot be broken by anything else. Anyone who has attained this condition is not susceptible to rebirth and suffering. Buddhists were convinced of the infinite possibilities of man to change his nature and "liberation". Buddhism advocated the religious doctrine of equality of all people in "suffering" and in the right to "salvation" 43 .

In Buddhist teachings, which began to penetrate to China from India in the 1st century AD, special attention was paid to a simple and natural life in harmony with nature and the Universe, which is also a characteristic part of Chinese Taoist philosophy. Buddhism did not opposite Confucianism and Taoism. From the very beginning, he acted as a supplement to them, as a practical teaching that guides the individual on the path of moral and intellectually elevated life. Buddhism was mixed with the Confucian worship of ancestors and the Taoist practices of divination. The interplay of Buddhism, Confucianism and Taoism led to the emergence of a special, Chinese version of Buddhism.

In traditional societies, to which we have reason to include the Chinese one, human subordination to customs, traditions, rituals, ethnic norms and stereotypes hinder its development. The personality is more oriented to the past, to the experience and traditions of the ancestors, than to the current tendencies and needs of social development ${ }^{44}$.

The attitude of Chinese society to the type of traditional and its tendency to focus on the past, the established and the traditional allows to draw conclusions about the final subjugation in the Chinese minds of the individual to the collective, which in turn is reduced to the levelling of personality traits and preventing the disclosure of personality in a person. However, addressing the anthropological issues of Chinese traditional scholars gives us the reason to conclude that personal tendencies still exist in them. In Confucianism, in particular, the leading position is occupied by the idea of a moral primordial person, her conscious desire for self-perfection through education, orientation to existing models of canonized noble men. The possibility of realization only within the limits of public (state) activity

42 Основы буддийского мировоззрения: Индия. Китай / В. Рудой, Е. Островская, А. Островский и др. Москва : Наука, 1994. С. 136.

43 Основы буддийского мировоззрения: Индия. Китай / В. Рудой, Е. Островская, А. Островский и др. Москва : Наука, 1994. С. 137.

44 Спешнев Н.А. Китайцы: особенности национальной психологии. Санкт Петербург : КАРО, 2011. С. 91. 
of Confucians does not deny the possibility of personality development, because even in the theory of French personalities at the beginning of $20^{\text {th }}$ century there was an idea: "I exist to the extent that I exist for another" ${ }^{\text {. }}$ Social motivation of personality development is rejected by Taoism, within which the idea of self-perfection of the person (in spiritual and physical terms), its constant change in order to approach the "true human essence" is enhanced. Taoism frees man from the material motivation of his life, which is also an important moment in the structure of personality formation. Quite important thing in Buddhist philosophy was the assertion that there was no individual "I". The recognition of the individual "I" by Buddhists was associated with ignorance. Buddhism proceeds from the fact that evil, suffering, difficulties and sorrows, failures, anxieties and other everyday problems stem from the inner psychological state of the individual, his "blindness". Thus, Buddhism called people not to combat injustice in the world, but to weaken human response to inner desires. In order to firmly take the path of salvation, a Buddhist must suppress his affection towards illusory being, and this can only be done if the individual is truly aware of the unreality of the existence of the individual "I". Buddhism believes that the highest degree of perfection is not only to reach the nirvana itself, but also to bring others to it, that is, to save not only themselves but also others.

\section{CONCLUSIONS}

Therefore, the implicit fact is that the personalistic tendencies of traditional Chinese scholars, especially Confucianism, have been largely leveled in the process of practical application. The primordial philosophical postulates often remained the perfect impracticable model, but all the rethinking of primitive theories and their adaptation to the imperial needs towards subjugation of Chinese people were quite prolific. That to a considerable extent formed the opinion of the researchers about the impossibility of forming in the minds of the Chinese the concept of "human personality", identical to its understanding within the limits of Western civilization. However, the presented above material certifies that in China at the beginning of the $20^{\text {th }}$ century the ideas of Western thinkers are actively assimilated, and the formation in the minds of Chinese of the concept of the "personality" of the Western sample is made possible by the presence of implicit personalistic tendencies in traditional Chinese teachings. In Confucianism, in particular, it is the idea of a moral primal in man, his conscious desire for self-improvement through education; in Taoism, material and social motivation is rejected, the idea of spiritual and physical

\footnotetext{
${ }^{45}$ Мунье Э. Манифест персонализма. Москва : Республика, 1999. С. 479.
} 
self-perfection is enhanced, a constant change is made in order to approach the true human essence.

\section{SUMMARY}

The article explores the role of Chinese and Western philosophical theories in the formation of the essential features of a person as a personality. The content of the concept of "personality", as set out in the works of European personalist philosophers (N. Berdyaev, E. Mounier), has been clarified. On the basis of a comparative analysis, the thesis of the impossibility of forming in the minds of the Chinese people the concept of «personality» in its European understanding is refuted.

\section{REFERENCES}

1. Бердяев Н. О рабстве и свободе человека. Опыт персоналистической философии. Царство Духа и Царство Кесаря. Москва : Республика, 1995. 375 с.

2. Бердяев Н. Самопознание (Опыт философской автобиографии). Москва : Книга, 1991. 446 с.

3. Большой китайско-русский словарь / БКРС. URL: http://bkrs.info (retrieved 25.01.2020).

4. Боэций. Новая философская энщиклопедия : в 4 т. / под ред. B.C. Стёпина. Москва : Мысль. 2001. URL: http://dic.academic.ru/dic.nsf/ enc_philosophy/162/БОЭЦИЙ_(retrieved 25.01.2020).

5. Вдовина И.С. Личность в современном мире. Манифест персонализма. Москва : Республика, 1999. 559 с.

6. Горохов А.Н. А. Бердяев и Э. Мунье (два опыта построения персоналистической философии). Вече. Журнал русской философии и культуры. 2009. № 19. С. 114-119.

7. Коваль С.Н., Холин Ю.Е. Дух воина. Дзэн и проблема человека. Краснодар : Маерли, 1993. 230 с.

8. Крысько В.Г. Этнопсихологический словарь. Национальная психологическая энииклопедия. URL: http://vocabulary.ru/dictionary/1067/ word/lichnost_(retrieved 25.01.2020).

9. Личность в традиционном Китае: сборник статей / редкол.: Л.П. Делюсин (отв. ред.) и др. Москва : Наука. Изд. фирма «Вост. лит», 1992. 325 c.

10. Мунье Э. Манифест персонализма. Москва : Республика, 1999. $560 \mathrm{c}$.

11. Основы буддийского мировоззрения: Индия. Китай / В. Рудой, Е. Островская, А. Островский и др. Москва : Наука, 1994. 239 с.

12. Персонализм. Новая философская энииклопедия. URL: http://iph.ras.ru/elib/ 2302.html (retrieved 25.01.2020). 
13. Рябов П. Проблема личности в философии классического анархизма : дисс. ... канд. филисоф. наук. Москва, 1996. URL: http://royallib.ru/book/ryabov_petr/problema_lichnosti_v_filosofii_klassiche skogo_anarhizma.html_(retrieved 25.01.2020).

14. Смирнов А. Даосизм и конфуцианство: единство и борьба противоположностей. URL: http://shkolazhizni.ru/archive/0/n-46130/ (retrieved 25.01.2020).

15. Спешнев Н.А. Китайцы: особенности национальной психологии. Санкт-Петербург : КАРО, 2011. 330 с.

16. Торопцев С.А. От схемы к характеру [Изображение человека в литературе и искусстве Китая]. Вопросы литературы. 1983. № 10. C. $86-112$.

17. Торчинов Е.А. Учение о «Я» и личности в классическом индийском буддизме. URL: http://psylib.org.ua/books/_torch01.htm (retrieved 25.01.2020).

18. Хамітов Н., Гармаш Л., Крилова С. Історія філософiї: Проблема людини та їі меж: навчальний посібник. Київ : КНТ, 2016. 396 c.

19. Штирнер М. Единственный и его собственность. Харьков: Основа, 1994.560 c.

20. Macgowan, John. Sidelights on Chinese Life. London: K. Paul, Trench, Trübner \& co., limited, 1907. 367 p.

21. 中国儒家学术思想史。济南：山东教育出版社1996年。1673页。 22. 启良。中国文明史。广州：花城出版社, 2001年。1143页。

\section{Information about the authors:} Kharyshyn D. G., $\mathrm{PhD}$ in Philology, Assistant Lecturer at the Department of Far Eastern and South Eastern Languages and Literatures Institute of Philology of Taras Shevchenko National University of Kyiv 60, Volodymyrska Str., Kyiv, 01033, Ukraine

Vorobei O. S., $\mathrm{PhD}$ in Philology, Assistant Lecturer at the Department of Far Eastern and South Eastern Languages and Literatures

Institute of Philology of Taras Shevchenko National University of Kyiv 60, Volodymyrska Str., Kyiv, 01033, Ukraine 